\title{
KONSEP HAK ASASI MANUSIA DALAM ISLAM (Mengungkap Korelasi Antara Islam Dengan HAM)
}

\author{
Yahya Ahmad Zein \\ email: yahyazein@yahoo.com
}

\begin{abstract}
The intention of this article is explore how Islamic teaching regards human rights. The main finding of this basic research is that in today's modern world, the universal values of human rights function as a glue binding society together. Although in pluralist modern society it become very difficult to impose one standard paradigm or worldview. In regard to Islam and human rights important is to take cognizance of the huquuqul ibad category. This enables us to differentiate between, firstly, the existence of human rights within a country and directly applicable and, secondly, human rights whose existence cannot be directly implemented by a country. Another finding is that there Islamic teaching does not contradict the universal value of human rights. There is a common ground (common values/kalimatun Sawa) between Shariah and human rights in which both demands the development of human virtues (rahmatal lil'alamin/ nurturing the whole universe)
\end{abstract}

Keywords:

Concepts, human rights, Islam

\begin{abstract}
Abstrak
Tujuan penulisan ini adalah mengeksplorasi ajaran Islam tentang hak asasi manusia. Temuan utama penelitian dasar ini adalah dalam pluralisme dunia modern saat ini nilai-nilai universal HAM merupakan elemen penting yang berfungsi sebagai perekat bagi kehidupan masyarakat, walaupun sangat sulit untuk memaksakan satu standar paradigma atau worldview tersebut. Berkenaan dengan itu, konsep hak asasi manusia dalam Islam harus dipahami berangkat darii kategori huquuqul ibad. Hal ini memungkinkan kita untuk membedakan hak asasi manusia yang dapat diselenggarakan oleh suatu negara dan yang tidak dapat langsung dilaksanakan. Temuan lain adalah adanya hubungan paralel antara ajaran Islam dengan HAM. Hal mana berarti bahwa nilai-nilai universal Islam tidak akan bertentangan dengan nilai-nilai universal hak asasi manusia. Ada titik temu (common values/kalimatun sawā) antara Syari'ah dengan konsep HAM dan konsep manusia yang menyerukan kebajikan-kebajikan yang menyeluruh (rahmatal lil'ālamin/yang mengayomi seluruh alam)
\end{abstract}

Kata Kunci: Konsep, HAM, Islam

\section{Pendahuluan}

Pada prinsipnya persoalan Hak Asasi Manusia (HAM) dalam semua asfek merupakan bagian dari tujuan pendirian suatu negara, bahkan dalam perspektif Teori Locke perlindungan hak-hak kodrati (hak asasi manusia) merupakan dasar dalam pendirian suatu negara. ${ }^{1}$ Setiap orang harus tunduk terhadap kekuasaan

\footnotetext{
${ }^{1}$ Carl J. Friedrich, The Philosophy of Law in Historical Perspektive, 101 (Chicago University, Chicago \& London, 1969).
} 
negara sepanjang dilakukan untuk menciptakan perdamaian, keamanan dan kesejahteraan serta melindunggi hak-hak kodrati rakyat, dimana hak-hak kodrati yang dilindunggi negara ini adalah hak-hak yang tidak dapat dipisahkan dan terpisahkan dari manusia sejak keadaan alamiah atau "state of nature", yaitu "life, liberty and estate". Negara hanya akan memperoleh legitimasi kekuasaannya dari rakyat apabila negara akan merealisasikan HAM rakyatnya.

Dalam hal hidup dan kebebasan inilah setiap orang seharusnya dapat memperoleh HAM yang layak, sehingga hal ini akan membawa implikasi pengembangan integritas setiap orang untuk hidup lebih baik dan bermartabat. Gagasan ini membawa kepada sebuah tuntutan moral tentang bagaimana seharusnya manusia memperlakukan sesama manusia sesuai dengan martabatnya sebagai manusia. Tuntutan moral ini sesuai dengan ajaran Agama bahkan lebih dari itu dapat dikatakan sebagai inti ajaran dari semua agama. ${ }^{2}$ Tuntutan moral tersebut diperlukan untuk melindungi seseorang atau sekelompok orang yang lemah (al-mustad'afin) dari tindakan dzalim dan semena-mena yang biasanya datang dari penguasa dan mereka yang memiliki kekuasaan, sehingga dalam konteks ini HAM adalah penghormatan terhadap kemanusiaan yang tidak terbatas pada orang tertentu atau pengecualiaan tertentu dan tanpa diskriminasi berdasarkan apapun dan alasan apapun termasuk alasan kekuasaan sekalipun, serta pengakuan terhadap martabat manusia sebagai mahluk di dunia yang memiliki kemuliaan.

Islam mengajarkan pentingnya penghormatan dan penghargaan terhadap sesama manusia, karena Islam sebagai agama yang membebaskan dan memanusiakan manusia, hal ini tercermin dalam Al-qur'an surah ke 49: 13

2 Ajaran Agama adalah sistem keprcayaan,keyakinan dan pengetahuan yang sampai kini masih di dominasi dan mengatur keberadaan banyak masyarakat,khusunya Islam kenyataan tersebut menjadi sangat penting karena berbagai gerakan revolusioner yang dikenal luas dan diasosiasikan dengan Islam menimbulkan yang semuanya mengatasnamakan Tuhan dan ajarannya. M.Arkoun, Islam Kontemporer menuju dialog antar agama di terjemahkan dari rethinking, 99-100 (Pustaka Pelajar, Jogjakarta,2001). 


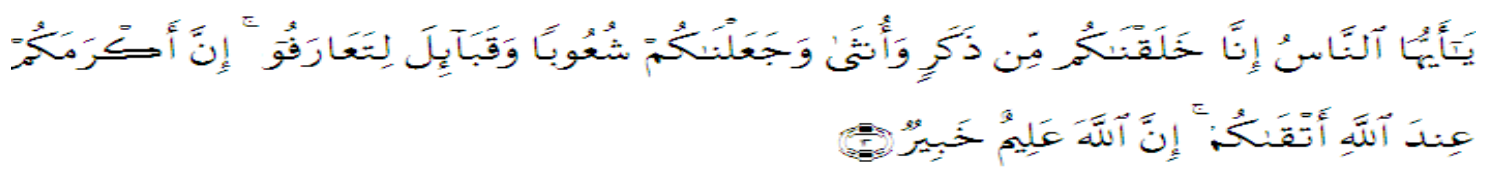

Artinya : Hai manusia, sesungguhnya Kami menciptakan kamu dari seorang lakilaki dan seorang perempuan dan menjadikan kamu berbangsa-bangsa dan bersuku-suku supaya kamu saling kenal mengenal. Sesungguhnya orang yang paling mulia di antara kamu di sisi Allah ialah orang yang paling bertakwa di antara kamu. Sesungguhnya Allah Maha Mengetahui lagi Maha Mengenal.

Kesadaran akan pentingnya penghormatan dan penghargaan terhadap sesama manusia dan kesadaran akan pentingnya HAM muncul bersamaan dengan kesadaran akan pentingnya menempatkan manusia sebagai titik sentral pembangunan (human centred development). Konsep HAM berakar dari penghargaan terhadap martabat manusia sehingga menempatkan manusia sebagai mahluk yang sangat berharga dan menempatkan manusia sebagai subjek bukan objek, yang memandang manusia sebagai makluk yang dihargai dan dihormati tanpa membedakan jenis kelamin, ras, ideologi, suku bangsa, bahasa dan agama. HAM mengajarkan prinsip-prinsip universal persamaan dan kebebasan manusia sehingga tidak boleh ada diskriminasi, eksploitasi, kekerasan terhadap sesama manusia, serta pembatasan dan pengekangan terhadap kebebasan dasar manusia. Dari sinilah pentingnya mengelaborasi nilai-nilai Universal HAM dalam perspektif Islam.

Berdasarkan latar belakang tersebut di atas, maka permasalahan yang akan dikaji disini adalah: Bagaimana Konsep HAM dalam Islam dalam rangka mengungkap korelasi antara Islam dan HAM?

\section{Prinsip Dasar Hak Asasi Manusia}

Pada prinsipnya Ide tentang hak asasi manusia yang berlaku saat ini merupakan senyawa yang dimasak di kancah Perang Dunia II. Selama perang tersebut, dipandang dari segi apa pun akan terlihat bahwa satu aspek berbahaya dari pemerintahan Hitler adalah tiadanya perhatian terhadap kehidupan dan 
kebebasan manusia. Karenanya, perang melawan kekuatan Poros dibela dengan mudah dari segi perlindungan hak asasi manusia dan kebebasan yang mendasar. Negara Sekutu menyatakan di dalam "Deklarasi Perserikatan Bangsa-Bangsa" (Declaration by United Nations) yang terbit pada 1 Januari 1942, bahwa kemenangan adalah "penting untuk menjaga kehidupan, kebebasan, independensi dan kebebasan beragama, serta untuk mempertahankan hak asasi manusia dan keadilan." Dalam pesan berikutnya yang ditujukan kepada Kongres, Presiden Franklin D. Roosevelt mengidentifikasikan empat kebebasan yang diupayakan untuk dipertahankan di dalam perang tersebut: kebebasan berbicara dan berekspresi, kebebasan beragama, kebebasan dari hidup berkekurangan, dan kebebasan dari ketakutan akan perang. ${ }^{3}$

Dampak dari Pembunuhan dan kerusakan dahsyat terhadap sendi-sendi kehidupan yang ditimbulkan Perang Dunia II menggugah suatu kebulatan tekad dunia untuk melakukan sesuatu guna mencegah perang, untuk membangun sebuah organisasi internasional yang sanggup meredakan krisis internasional serta menyediakan suatu forum untuk diskusi dan mediasi. Organisasi ini adalah Perserikatan Bangsa-Bangsa (PBB), yang telah memainkan peran utama dalam pengembangan pandangan kontemporer tentang hak asasi manusia.

Para pendiri PBB yakin bahwa pengurangan kemungkinan terjadinya perang mensyaratkan adanya pencegahan atas pelanggaran besar-besaran terhadap hak-hak asasi manusia. Lantaran keyakinan ini, konsepsi-konsepsi PBB yang paling awal pun bahkan sudah memasukkan peranan pengembangan hak asasi manusia dan kebebasan. Naskah awal Piagam PBB (1942 dan 1943) memuat ketentuan tentang hak asasi manusia yang harus dianut oleh negara manapun yang bergabung di dalam organisasi tersebut, namun sejumlah kesulitan muncul berkenaan dengan pemberlakuan ketentuan semacam itu. Lantaran mencemaskan prospek kedaulatan mereka, banyak negara bersedia untuk "mengembangkan"

\footnotetext{
${ }^{3}$ Lihat Douglas Lurton, Roosevelt's Foreign Policy, 1933 1941: Franklin D. Roosevelt's Unedited Speeches, 324 (Longmans, Green, Toronto,1942).
} 
hak asasi manusia namun tidak bersedia "melindungi" hak itu. ${ }^{4}$ Akhirnya diputuskan untuk memasukkan sedikit saja acuan tentang hak asasi manusia di dalam Piagam PBB (UN Charter), di samping menugaskan Komisi Hak Asasi Manusia (Commission on Human Rights). ${ }^{5}$ Untuk menulis sebuah pernyataan internasional tentang hak asasi manusia. Piagam itu sendiri menegaskan kembali "keyakinan akan hak asasi manusia yang mendasar, akan martabat dan harkat manusia, akan persamaan hak antara laki-laki dan perempuan serta antara negara besar dan negara kecil." Para penandatangannya mengikrarkan diri untuk "melakukan aksi bersama dan terpisah dalam kerja sama dengan Organisasi ini "untuk memperjuangkan" penghargaan universal bagi, dan kepatuhan terhadap, hak asasi manusia serta kebebasan-kebebasan mendasar untuk seluruh manusia, tanpa membedakan ras, jenis kelamin, bahasa atau agama."6

Hak asasi manusia, sebagaimana yang dipahami di dalam dokumendokumen hak asasi manusia yang muncul pada abad kedua puluh seperti Deklarasi Universal, mempunyai sejumlah ciri menonjol: ${ }^{7}$

4 Pernyataan Umum tentang Hak-Hak Asasi Manusia (Bahasa Inggris: Universal Declaration of Human Rights ; singkatan: UDHR) adalah sebuah pernyataan yang bersifat anjuran yang diadopsi oleh Majelis Umum Persatuan Bangsa-Bangsa (A/RES/217, 10 Desember 1948 di Palais de Chaillot, Paris). Pernyataan ini terdiri atas 30 pasal yang menggarisbesarkan pandangan Majelis Umum PBB tentang jaminan hak-hak asasi manusia (HAM) kepada semua orang. Eleanor Roosevelt, ketua wanita pertama Komisi HAM (Bahasa Inggris: Commission on Human Rights; singkatan: CHR] yang menyusun deklarasi ini, mengatakan, "Ini bukanlah sebuah perjanjian [Di masa depan] ini mungkin akan menjadi Magna Carta internasional. (Eleanor Roosevelt: Address to the United Nations General Assembly 9 December 1948 in Paris, France).

5 komisi yang dibentuk PBB berdasarkan sebuah ketetapan di dalam piagam tersebut, Komisi Hak Asasi Manusia mempersiapkan sebuah pernyataan internasional tentang hak asasi manusia yang disetujui oleh Majelis Umum pada tanggal 10 Desember 1948. Pernyataan ini, yaitu Deklarasi Universal Hak Asasi manusia (Universal Declaration of Human Rights), diumumkan sebagai "suatu standar pencapaian yang berlaku umum untuk semua rakyat dan semua negara" Hak-hak yang disuarakannya disebarkan lewat "pengajaran dan pendidikan" serta lewat "langkahlangkah progresif, secara nasional dan internasional, guna menjamin pengakuan, dan kepatuhan yang bersifat universal dan efektif terhadapnya.

${ }^{6}$ Ian Brownlie dalam James W Nikel, ed.. Basic Documents on Human Rights 93-105 (Clarendon Press ,Oxford,1971).

7 James W. Nickel, Hak Asasi Manusia: Making Sense Of Human Right, Refleksi Filosofis atas Deklarasi Universal Hak Asasi Manusia, (Gramedia Pustaka Utama, Jakarta, 1996). 
1. Pertama, supaya kita tidak kehilangan gagasan yang sudah tegas, hak asasi manusia adalah hak. Hal tersebut menunjukkan bahwa hak itu adalah normanorma yang pasti dan memiliki prioritas tinggi yang penegakkannya bersifat wajib.

2. Hak-hak ini dianggap bersifat universal, yang dimiliki oleh manusia sematamata karena ia adalah manusia. Pandangan ini menunjukkan secara tidak langsung bahwa karakteristik seperti ras, jenis kelamin, agama, kedudukan sosial, dan kewarganegaraan tidak relevan untuk mempersoalkan apakah seseorang memiliki atau tidak memiliki hak asasi manusia. Ini juga menyiratkan bahwa hak-hak tersebut dapat diterapkan di seluruh dunia. Salah satu ciri khusus dari hak asasi manusia yang berlaku sekarang adalah bahwa itu merupakan hak internasional. Kepatuhan terhadap hak serupa itu telah dipandang sebagai obyek perhatian dan aksi internasional yang sah.

3. Hak asasi manusia dianggap ada dengan sendirinya, dan tidak bergantung pada pengakuan dan penerapannya didalam sistem adat atau sistem hukum di negara-negara tertentu. Hak ini boleh jadi memang belum merupakan hak yang efektif sampai ia dijalankan menurut hukum, namun hak itu eksis sebagai standar argumen dan kritik yang tidak bergantung pada penerapan hukumnya.

4. Hak asasi manusia dipandang sebagai norma-norma yang penting. Meski tidak seluruhnya bersifat mutlak dan tanpa perkecualian, hak asasi manusia cukup kuat kedudukannya sebagai pertimbangan normatif untuk diberlakukan di dalam benturan dengan norma-norma nasional yang bertentangan, dan untuk membenarkan aksi internasional yang dilakukan demi hak asasi manusia. Hakhak yang dijabarkan di dalam Deklarasi tersebut tidak disusun menurut prioritas; bobot relatifnya tidak disebut. Tidak dinyatakan bahwa beberapa di antaranya bersifat absolut. Dengan demikian hak asasi manusia adalah sesuatu yang oleh para filsuf disebut sebagai prima facie rights. ${ }^{8}$

8 Kebanyakan hak adalah hak prima facie yang artinya hak itu berlaku sampai dikalahkan oleh hak lain yang lebih kuat. Misalnya Kebebasan merupakan salah satu hak yang sangat penting namun hak ini tidak dapat dikatakan hak absolut karena hak ini juga dapat dikalahkan oleh hak lain. 
5. Hak-hak ini mengimplikasikan kewajiban bagi individu maupun pemerintah. Adanya kewajiban ini, sebagaimana halnya hak-hak yang berkaitan dengannya, dianggap tidak bergantung pada penerimaan, pengakuan, atau penerapan terhadapnya. Pemerintah dan orang-orang yang berada di mana pun diwajibkan untuk tidak melanggar hak seseorang, kendati pemerintah dari orang tersebut mungkin sekaligus memiliki tanggung jawab utama untuk mengambil langkah-langkah positif guna melindungi dan menegakkan hak-hak orang itu.

Akhirnya, hak-hak ini menetapkan standar minimal bagi praktek kemasyarakatan dan kenegaraan yang layak. Secara umum, HAM dapat di klasifikasikan menjadi empat hal pokok. Pertama, hak individual atau hak-hak yang dimiliki setiap orang. Hak individual disini menyangkut pertama-tama adalah hak yang dimiliki individu-individu terhadap Negara dan Negara tidak boleh menghindari atau mengganggu individu dalam mewujudkan hak-hak yang ia milki. Contoh: hak beragama, hak mengikuti hati nurani, hak mengemukakan pendapat, dll. Kedua, hak kolektif atau hak masyarakat, disini bukan hanya hak kepentingan terhadap Negara saja, akan tetapi sebagai anggota masyarakat bersama dengan anggota-anggota lain. Inilah yang disebut dengan hak sosial. Hakhak ini bersifat kolektif yang hanya dapat dinikmati bersama orang lain,seperti hak akan perdamaian, hak akan pembangunan dan hak akan lingkungan hidup yang bersih. Ketiga, hak sipil dan politik, antara lain memuat hak-hak yang telah ada dalam perundang-undangan Indonesia seperti: hak atas penentuan nasib sendiri; hak memperoleh ganti rugi bagi mereka yang kebebasannya dilanggar; hak atas kebebasan berfikir; hak atas kebebasan berekspresi. Keempat, hak

Seseorang yang mengalami gangguan jiwa dan membahayakan masyarakat sekitarnya dipaksa untuk dimasukkan ke dalam rumah sakit jiwa meskipun ia menolak. Kebebasan yang dimiliki orang tersebut merupakannya namun hak tersebut akhirnya kalah oleh hak masyarakat yang merasa terancam jiwanya. Hak tidak selalu bersifat absolut karena sesuatu hak akan kalah oleh alasan atau keadaan tertentu lain yang dapat menggugurkan posisi hak tersebut. 
ekonomi, sosial dan budaya (EKOSOB), ${ }^{9}$ antara lain memuat jaminan hak-hak warga yaitu: Hak atas pekerjaan; Hak mendapatkan program pelatihan; Hak mendapatkan kenyamanan dan kondisi kerja yang baik; Hak membentuk serikat buruh; Hak menikmati jaminan sosial, termasuk asuransi sosial; Hak menikmati perlindungan pada saat dan setelah melahirkan; Hak atas standar hidup yang layak termasuk pangan sandang, dan perumahan; Hak terbebas dari kelaparan; Hak menikmati standar kesehatan fisik dan mental yang tinggi; Hak atas pendidikan, termasuk pendidikan dasar secara cuma-Cuma; Hak untuk berperan serta dalam kehidupan budaya menikmati manfaat dari kemajuan ilmu pengetahuan dan aplikasinya.

Pada prinsipnya universalitas HAM dalam konteks ini adalah setiap orang berhak memiliki hak-hak tersebut tanpa harus ada syarat tertentu karena kedudukannya sebagai manusia, jadi setiap manusia tanpa ada pembedaan harus diperlakukan sesuai dengan hak-hak tersebut dan merupakan sarana etis dan hukum untuk melindungngi individu, kelompok dan golongan yang lemah terhadap kekuatan-kekuatan dalam masyarakat modern.

\section{Konsep Islam Tentang HAM}

Hak asasi pada dasarnya menunjukkan kekuasaan atau wewenang yang dimiliki seseorang bersifat mendasar. Oleh karena hak asasi bersifat mendasar dan fundamental, maka pemenuhannya bersifat imperatif. Hal ini sejalan dengan konsep Islam khususnya prinsip Tauhid yang merupakan ajaran paling mendasar dalam Islam. Tauhid ${ }^{10}$ memiliki efek pembebasan diri (self-liberation) sekaligus

9 Pemerintah Indonesia telah meratifikasi kovenan Internasioanal tentang Hak-hak EKOSOB (International Covenant on Economic, social, and Cultural Right) pada Oktober 2005. Ratifikasi ini ditandai dengan terbitnya UU No. 11 Tahun 2005 tentang Pengesahan International Convenant on Economic, Social and Cultural Right (Kovenan Internasional tentang Hak-hak Ekonomi, Sosial dan Budaya). Dengan demikian, negara wajib menghormati, melindungi dan memenuhi Hak-hak tersebut kepada warganya. Ada 143 negara yang meratifikasi kovenan tersebut, termasuk Indonesia.

10 Tauhid (Arab ت وح يد), adalah konsep dalam aqidah Islam yang menyatakan keesaan Allah. Tauhid dibagi menjadi 3 macam yakni tauhid rububiyah, uluhiyah/ibadah dan Asma wa 
juga pembebasan sosial, salah satu dari implikasi pembebasan sosial itu adalah paham egalitarianisme, yaitu bahwa semua manusia setara di hadapan Tuhan, yang membedakan hanyalah derajat ketakwaannya saja. Dampak paling nyata emansipasi harkat dan martabat kemanusiaan karena keimanan kepada Allah adalah terwujudnya pola hubungan antar manusia dalam semangat egalitarianisme. Karena setiap pribadi manusia berharga sebagai mahluk Tuhan yang bertanggung jawab langsung kepada-Nya, tidak seorangpun dari mereka yang dibenarkan di ingkari hak-hak asasinya, sebagaimana tidak seorangpun dari mereka yang di benarkan mengingkari hak asasi manusia lain.

Menurut Miriam Budiardjo, Hak Asasi adalah hak yang dimiliki manusia yang telah diperoleh dan dibawanya bersamaan dengan kelahiran atau kehadirannya di dalam kehidupan masyarakat. Dianggap bahwa beberapa hak itu dimilikinya tanpa perbedaan atas dasar negara, ras, agama, dan kelamin dan karena itu bersifat asasi serta universal. Dasar ini dari semua hak asasi adalah bahwa manusia harus memperoleh kesempatan untuk berkembang sesuai dengan bakat dan cita-cita. ${ }^{11}$

Konsep hak asasi manusia dalam Islam dibagi dua macam dilihat dari kategori huquuqul ibad. Pertama, HAM yang keberadaannya dapat diselenggarakan oleh suatu negara (Islam). Kedua, adalah HAM yang keberadaannya tidak secara langsung dapat dilaksanakan oleh suatu negara. Hakhak yang pertama disebut sebagai hak-hak legal, sedangkan yang kedua dapat disebut sebagai hak-hak moral.12 Perbedaan antara keduanya hanya terletak pada

Sifat/nama dan sifat baik (asma'ul husna). Mengamalkan tauhid dan menjauhi syirik merupakan konsekuensi dari kalimat sahadat yang telah diikrarkan oleh seorang muslim. Kedudukan Tauhid dalam Islam. Seorang muslim meyakini bahwa tauhid adalah dasar Islam yang paling agung dan hakikat Islam yang paling besar, dan merupakan salah satu syarat merupakan syarat diterimanya amal perbuatan disamping harus sesuai dengan tuntunan rasulullah. (http://wikipedia.org).

11 Miriam Budiardjo, Dasar-dasar Ilmu Politik, 120 (Penerbit PT. Gramedia Pustaka Utama, Jakarta, 1999).

12 Syekh Syaukat Hussain (Terjemahan Abdul Rochim C.N), Hak Asasi Manusia dalam Islam, 55 (Penerbit Gema Insani Pers, Jakarta, 1996). 
masalah pertanggungjawaban di depan Negara. Adapun masalah sumber, sifat, dan pertanggungjawaban di hadapan Allah adalah sama.

Dalam Islam keserasian kesucian HAM jauh lebih besar daripada hanya sekedar ibadah-ibadah ritual. Jika seseorang tidak memenuhi kewajibannya di hadapan Allah dia mungkin saja masih bisa diampuni. Namun tidak demikian dalam kasus tidak memenuhi kewajiban kepada sesama manusia.

Dalam Undang-undang Nomor 39 Tahun 1999 tentang Hak Asasi Manusia pada pasal 1, hak asasi manusia pada dasarnya juga disandarkan kepada hakikat keberadaan manusia sebagai mahluk Tuhan dimana HAM diartikan sebagai seperangkat hak yang melekat pada hakikat keberadaan manusia sebagai makhluk Tuhan Yang Maha Esa dan merupakan anugerah-Nya yang wajib dihormati dan dijunjung tinggi oleh negara, hukum, pemerintah, dan setiap orang demi kehormatan serta perlindungan harkat dan martabat manusia.

Jika ditelaah lebih jauh dasar pemikiran pembentukan Undang-undang No. 39 Tahun 1999 tentang HAM tersebut juga pada prinsipnya di dasarkan pada keberadaan manusia sebagai mahluk Tuhan, hal ini dapat kita lihat dari penjelasan umum UU No. 39 Tahun 1999 yang menyatakan bahwa dasar pemikiran pembentukan UU No. 39 Tahun 1999 adalah sebagai berikut:

a. Tuhan Yang Maha Esa adalah pencipta alam semesta dengan segala isinya dan pada dasarnya, manusia dianugerahi jiwa, bentuk, struktur, kemampuan, kemauan serta berbagai kemudahan oleh penciptanya, untuk menjamin kelanjutan hidupnya;

b. Untuk melindungi, mempertahankan, dan meningkatkan martabat manusia, diperlukan pengakuan dan perlindungan hak asasi manusia, karena tanpa hal tersebut manusia akan kehilangan sifat dan martabatnya, sehingga dapat mendorong manusia menjadi serigala bagi manusia lainnya (homo homini lupus); 
c. Karena manusia merupakan makhluk sosial, maka hak asasi manusia yang satu dibatasi oleh hak asasi manusia yang lain, sehingga kebebasan atau hak asasi manusia bukanlah tanpa batas;

d. Hak asasi manusia tidak boleh dilenyapkan oleh siapapun dan dalam keadaan apapun;

e. Setiap hak asasi manusia mengandung kewajiban untuk menghormati hak asasi manusia orang lain, sehingga di dalam hak asasi manusia terdapat kewajiban dasar;

f. Hak asasi manusia harus benar-benar dihormati, dilindungi, dan ditegakkan, dan untuk itu pemerintah, aparatur negara, dan pejabat publik lainnya mempunyai kewajiban dan tanggung jawab menjamin terselenggaranya penghormatan, perlindungan, dan penegakan hak asasi manusia.

Darji Darmodihardjo menyatakan bahwa hak asasi manusia adalah hak-hak dasar atau hak-hak pokok yang dibawa manusia sejak lahir sebagai anugerah Tuhan Yang Maha Esa. ${ }^{13}$ Mengingat hak maupun kesamaan telah diberikan Tuhan kepada manusia tanpa membedakan jenis kelamin, maka manusia sebagai kalifah Tuhan di bumi harus bisa melaksanakan hak-hak asasi tersebut dengan baik dan bertanggungjawab, karena penuntutan hak hak secara mutlak tentunya akan menyebabkan dilanggarnya hak-hak asasi orang lain. Dengan demikian dalam kehidupan di masyarakat pelaksanaan hak-hak asasi tersebut hurus dibarengi dengan kewajiban-kewajiban asasi. ${ }^{14}$

Menurut A. Masyur Effendi, "Hak asasi manusia adalah hak milik bersama umat manusia yang diberikan oleh Tuhan untuk "selama hidup" disamping definisi/pengertian hak asasi manusia menurut piagam PBB dan piagam-piagam lainnya. Karena itu dapat dikatakan bahwa hak asasi manusia adalah hak yang diberikan Tuhan atau manifestasi hak istimewa manusia sehingga tidak dapat

13 A. Masyur Effendi, Tempat Hak-hak Asasi Manusia dalam Hukum Internasional/Nasional, 20 (Penerbit Alumni, Bandung, 1980).

14 Mashood A. Baderin, International Human Rights And Islamic Law, 13 (Oxford University Press, London, 2003). 
tidak harus berada pada manusia. ${ }^{15}$ Sedangkan R. Kirk memberi definisi, "Human Rights as signifying all privileges and ammunities prosseses by human being in a civil social order". ${ }^{16}$

Ada Beberapa pendapat yang memberikan pemahaman tentang definisi Hak Asasi Manusi (HAM):

1. HAM adalah hak dasar sejak lahir merupakan anugerah dari Allah SWT;

2. HAM adalah hak yang dimiliki manusia sejak kelahirannya;

3. HAM adalah hak yang melekat pada diri manusia, tanpa hak itu manusia tidak dapat hidup secara layak;

4. HAM adalah seperangkat hak-hak yang melekat pada hakikat dan keberadaban manusia sebagaimakhluk tuhan Yang Maha Esa.

Secara umum HAM adalah hak-hak yang secara inheren melekat dalam diri manusia, yang tanpanya manusia tidak dapat hidup sebagai manusia. HAM di dasarkan pada prinsip fundamental bahwa semua manusia memiliki martabat yang inheren tanpa mamandang jenis kelamin, ras, warna kulit, bahasa, asal-usul bangsa, umur, kelas, keyakinan politik, dan agama. Semua orang berhak menikmati haknya tersebut. ${ }^{17}$

Berkaitan dengan pertanyaan dari mana HAM berasal setidaknya ada dua pendekatan yang mencoba menjawab pertanyaan ini.

Pertama, Pemikiran yang mendasarkan pandangannya pada ajaran agama atau merujuk pada nilai-nilai Ilahiah (wahyu Allah) sebagai kekuatan yang mengatasi manusia dan keberadaannya tidak tergantung kepada umat manusia. Agama-agama memberikan argumen yang sangat jelas bahwa manusia berawal dan berakhir pada sang pencipta. Tidak ada satupun yang berhak menguasai atau bertindak sewenang-wenang terhadap manusia. Oleh karena itu HAM adalah anugerah Tuhan YME, maka perlindungan atas manusia merupakan bagian

\footnotetext{
15 A. Masyur Effendi, opcit, hal.20.

16 Id.

17 Muhammad Yasir Alimi, Advokasi Hak-Hak Perempuan: Membela Hak Mewujudkan Perubahan, (LKIS ,Yogyakarta,1999).
} 
tanggung jawab manusia terhadap Tuhan. Agama Islam menempatkan manusia pada posisi kemuliaan yang sangat tinggi, kemuliaan itulah Islam melindungi jiwa manusia dari ancaman sesamanya.

Perlindungan tersebut bertujuan untuk menyelamatkan dan memelihara eksistensi manusia. Sehingga, pembunuhan atas satu jiwa manusia, pada hakikatnya sama seperti membunuh semua manusia. Dalam Islam misalnya dapat kita temukan penjelasan Al-quran sebagai berikut:

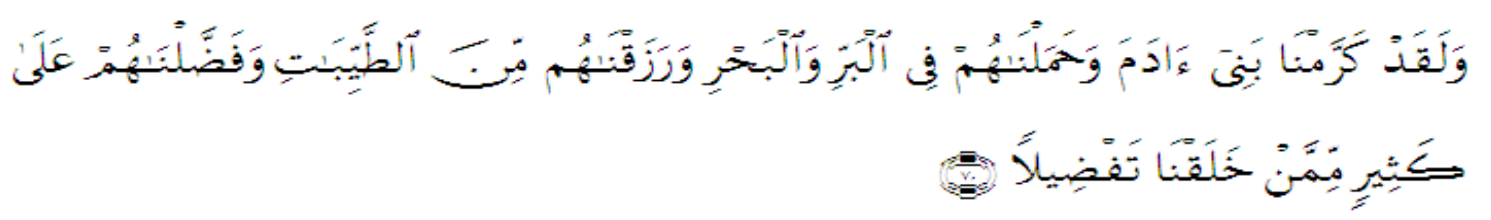

"Dan sesungguhnya kami telah memuliakan keturunan Adam, dan kami angkat mereka di daratan dan di lautan." kami beri mereka rejeki dari yang baik-baik dan kami lebihkan mereka dengan kelebihan yang sempurna atas kebanyakan mahluk yang telah kami ciptakan. (QS.17:70).

Kedua, pemikiran yang tidak secara langsung mendasarkan diri pada Agama karena pemikiran ini sangat beragam. Ada yang didasarkan pada suatu prinsip bahwa agar manusia bisa hidup di bawah nilai kemanusiaan memerlukan syarat objektif, yang bila syarat tersebut tidak terpenuhi maka nilai kemanusiaan akan hilang dan manusia akan musnah.

Dari berbagai penjelasan di atas dapat ditegaskan bahwa keberadaan hak asasi tidak tergantung pada dan bukan berasal dari manusia, melainkan berdasarkan dari instansi yang lebih tinggi dari manusia. Oleh karena itu, HAM tidak bisa dicabut dan tidak bisa dibatalkan oleh hukum positif manapun. Hukum positif harus diarahkan untuk mengadopsi dan tunduk pada HAM dan bila ada yang bertentangan, maka hak asasi yang harus dimenangkan.

\section{Korelasi Antara Islam Dengan HAM}

Pada saat kita berbicara soal HAM maka sesungguhnya tidak terlepas dari prinsip universalitas dari HAM yang merupakan elemen penting dalam HAM 
berupa pengakuan, penghormatan, persamaan dan kebebasan dari diskriminasi, jika kita kaitkan dengan Islam maka elemen-elemen HAM tersebut, terdapat dalam sumber Islam (Syari'ah). Memang al-Qur'an tidak berbicara spesifik tentang HAM. Mengenai HAM, Al-Qur'an berbicara pada tataran prinsip yang universal seperti: keadilan, musyawarah, saling menolong, menolak diskriminasi, menghormati kaum wanita, kejujuran, dan lain sebagainya. Rincian atas konsepkonsep itu dilakukan dalam Hadis dan tradisi tafsir. Karena itu, nilai-nilai HAM adalah kelanjutan dari prinsip-prinsip ajaran Islam di atas. Perbedaan antara Syari'ah dan konsep HAM terjadi pada aspek-aspek rinci (furu'iyyah) walaupun secara prinsipal tidak ada problem. ${ }^{18}$

Sebagaimana Kung dan Moltmann dalam "The Ethics of World Religions and Human Rights" menulis bahwa hampir semua agama besar di dunia memiliki masalah dalam mewujudkan pasal-pasal hak asasi yang tercantum dalam Declaration of Human Rights. ${ }^{19}$ Jika kita ingin mendiskusikan hubungan antara Islam dan HAM Salah satu kesulitan yang dihadapi adalah adanya fakta bahwa dalam Islam ada beberapa mazhab dan aliran pemikiran yang berkembang sehingga pasti akan ada perbedaan konsep dalam memandang hal tersebut. Meskipun demikian, cendekiawan Muslim yang konsen terhadap isu relativisme budaya dan HAM secara garis besar terbagi kepada dua kelompok. Afshari (1994) menyebutnya sebagai kelompok old-traditionalist dan new-traditionalist, sementara Bielefeldt (1995) menyebut mereka sebagai kelompok konservatif ${ }^{20}$

18 Perbedaan pada furu'iyyah (cabang) muncul pada tataran aplikatif, setelah terjadi kesepakatan pada masalah-masalah dasar prinsipil dan kaidah kulliyah. Perbedaan aplikasi ini sangat mungkin terjadi karena memang Allah telah jadikan furu' (cabang) syari'ah agama terbuka untuk dianalisa dan dikaji aplikasinya.

19 Hans Kung and Jiirgen Moltmann, eds., The Ethics of World Religions and Human Rights 102119, (Philadelphia. Concilium, New York, NY, USA, 1990).

20 Konservatisme adalah sebuah filsafat politik yang mendukung nilai-nilai tradisional. Istilah ini berasal dari kata dalam bahasa Latin, conservāre, melestarikan; "menjaga, memelihara, mengamalkan". Karena berbagai budaya memiliki nilai-nilai yang mapan dan berbeda-beda, kaum konservatif di berbagai kebudayaan mempunyai tujuan yang berbeda-beda pula. Sebagian pihak konservatif berusaha melestarikan status quo, sementara yang lainnya berusaha kembali kepada nilai-nilai dari zaman yang lampau, the status quo ante (Lihat http://wikipedia.org) 
dan liberal. ${ }^{21}$ Kelompok konservatif menolak untuk memaksakan standar Barat diterapkan pada masalah-masalah publik masyarakat Muslim. Bagi mereka, urusan publik dalam masyarakat Islam telah diatur secara jelas oleh norma agama. Bagi kelompok ini, universalitas HAM yang dipromosikan oleh PBB dan negara-negara Barat adalah ancaman bagi kelangsungan hidup masyarakat Muslim. Meskipun demikian, kelompok ini tidak serta-merta menolak seluruh konsep tentang HAM yang ditawarkan Barat, mereka menawarkan solusi dengan penekanan pada perlunya masyarakat Islam merumuskan konsep HAM dengan framework yang islami. Kelompok liberal di pihak lain telah jauh melangkah dengan mencoba menafsirkan teks-teks sakral agama dengan cara mengembangkan metodologi penafsiran baru. Bagi kelompok ini diperlukan reinterpretasi baru atas nilai-nilai Islam untuk memenuhi tuntunan norma global. Ahmed An-Naim (1994), seorang cendekiawan hukum Islam yang konsen dengan HAM, mengatakan bahwa secara substantif nilai-nilai Islam sangat mendukung dan sejalan dengan norma legal HAM yang dikembangkan Barat jika nilai-nilai Islam ditafsirkan secara akurat. Untuk mendukung pernyataannya, Naim menunjuk elastisitas Islam yang memiliki kafabilitas tinggi dalam mengakomodasi variasi interpretasi teks. Lebih jauh, kaum liberal Muslim memandang bahwa tidak ada kontradiksi yang prinsipil antara nilai-nilai Islam dan standard HAM internasional yang dikembangkan PBB. Ide-ide Al-Quran tentang tingginya martabat manusia, perlunya solidaritas kemanusiaan bahkan tidak adanya pemaksaan dalam beragama menunjukkan bahwa Islam sangat menghargai HAM. ${ }^{22}$

Kontroversi antara kaum konservatif dan liberal Muslim tentang hubungan antara Islam dan HAM sampai saat ini bahkan mungkin sampai akhir zaman masih belum berakhir. Namun, untuk mensinergikan dan membangun suatu konsep

21 Liberalisme atau Liberal adalah sebuah ideologi, pandangan filsafat, dan tradisi politik yang didasarkan pada pemahaman bahwa kebebasan adalah nilai politik yang utama. Secara umum, liberalisme mencita-citakan suatu masyarakat yang bebas, dicirikan oleh kebebasan berpikir bagi para individu. Paham liberalisme menolak adanya pembatasan, khususnya dari pemerintah dan agama (http://wikipedia.org)

22 Lihat Al-Qur'an Surah ke 109: 6 
tentang HAM dengan framework Islami, seperti ditekankan kaum konservatif, masyarakat Muslim telah berhasil menyusun dua deklarasi tentang HAM: The Universal Islamic Declaration of Human Rights yang dirumuskan oleh IslamicCouncil Eropa pada tahun $1981^{23}$ dan Cairo Declaration of Human Rights in Islam²4yang diadopsi oleh Organisasi Konferensi Islam pada Agustus 1991 sebagai acuan HAM dalam Islam. Untuk melihat apakah ada kontradiksi antara deklarasi HAM produksi Barat yang dipromosikan PBB dan Islam, beberapa contoh pasal yang diambil dari Universal Declaration of Human Rights dan Universal Islamic Declaration of Human Rights dicoba didiskusikan di sini. Pasal 16 deklarasi HAM versi PBB menyebutkan bahwa "wanita dan laki-laki dewasa, tanpa batasan ras, warga negara, atau agama berhak untuk menikah dan memiliki keluarga". Keduanya baik laki-laki maupun wanita memiliki hak yang sama untuk menikah, selama pernikahan dan hak untuk bercerai. Pasal ini jelas kontradiktif dengan

23 Dewan Islam Eropa (diresmikan di London pada tahun 1973) di bawah pengelolaan dari Salem diplomat Saudi-Mesir Azzam, didirikan sebuah jaringan yang unik pemikir Islam dan negarawan yang datang bersama-sama dalam serangkaian konferensi dan seminar diadakan di London pada akhir tahun 70-an dan 80-an untuk merumuskan dan mengartikulasikan posisi Islam tentang berbagai isu kontemporer. Following a conference held at the Albert Hall in 1980 on the theme 'Message of Muhammad', a smaller group worked on a response to the UN Declaration of Human Rights. Setelah konferensi yang diadakan di Albert Hall pada tahun 1980 dengan tema 'Pesan Muhammad', sebuah kelompok yang lebih kecil bekerja pada respon dengan Deklarasi PBB Hak Asasi Manusia. Those involved in its many discussions - held at the ICE's offices in 16 Grosvenor Crescent, Hyde Park Corner - were the former Sudanese Prime Minister Sadiq Al-Mahdi, the two leading Pakistani legal experts of the day AK Brohi and Khalid Ishaque, and judge Midhat Azzam and Dr Kholi from Egypt. Mereka yang terlibat dalam diskusi dengan banyak - yang diadakan di kantor ICE di 16 Grosvenor Crescent, Hyde Park Corner adalah Sudan mantan Perdana Menteri Sadiq Al-Mahdi, dua para ahli hukum Pakistan hari AK Brohi dan Khalid Ishaque, dan hakim Midhat Azzam dan Dr Kholi dari Mesir. The outcomes were two seminal papers that capture Muslim thinking of the period: 'A model of an Islamic Constitution', published in 1983, and the 'Universal Islamic Declaration Human Rights' published two years ealier(see below).

24 Deklarasi Kairo Hak Asasi Manusia dalam Islam (CDHRI) merupakan deklarasi negara-negara anggota Organisasi Konferensi Islam diadopsi di Kairo pada tahun 1990, yang memberikan gambaran umum pada perspektif Islam tentang hak asasi manusia, dan menegaskan Islam syariah sebagai yang satu-satunya sumber. CDHRI declares its purpose to be "general guidance for Member States [of the OIC] in the Field of human rights". CDHRI menyatakan tujuannya untuk menjadi "pedoman umum untuk Negara Anggota [dari OKI] di Bidang hak asasi manusia". This declaration is usually seen as an Islamic response to the post- World War II United Nations ' Universal Declaration of Human Rights (UDHR) of 1948. Deklarasi ini biasanya terlihat sebagai respon Islam pasca- Perang Dunia II PBB ' Deklarasi Universal Hak Asasi Manusia (UDHR) dari 1948 . 
norma Islam yang melarang wanita Islam menikah dengan non-Muslim. Pasal 18 menyebutkan bahwa, "Setiap orang memiliki hak kebebasan untuk berpendapat dan beragama, termasuk hak untuk pindah agama". Hak untuk pindah agama banyak ditentang oleh beberapa negara Islam, meskipun Al Quran mengatakan bahwa tidak ada paksaan dalam beragama. Isu krusial tentang larangan konversi agama dari Islam kepada non-Islam masih banyak ditentang dalam konsep kebebasan beragama di negara-negara Islam.

Beberapa pasal dalam Universal Islamic Declaration of Human Rights juga sangat terbuka untuk dikritik. Sebagai contoh pasal 6 menyebutkan bahwa, "Wanita memiliki hak yang sama dengan laki-laki", padahal dalam tataran realitas masih ada negara-negara Islam yang memposisikan wanita sebagai makhluk kelas dua. Poin lain yang menarik adalah pasal 23 yang mengatakan bahwa, "Karena dalam pandangan Islam negara Islam adalah Ummah Islamiah, maka setiap Muslim memiliki hak secara bebas untuk keluar-masuk negara Islam". Dalam realitas sosial ini sangat sulit untuk diterapkan, sebagaimana dunia global sekarang mengenal batasan negara dan bangsa, tentunya adalah tidak mungkin misalnya, Muslim Indonesia dengan seenaknya keluar masuk Saudi Arabia, Kuwait, atau negara Islam lainnya tanpa memiliki paspor dan visa. Pemaparan di atas dengan jelas mengindikasikan bahwa perbedaan tafsir atas konsep HAM muncul di mana-mana termasuk dalam tradisi Islam. Sekarang, tantangan bagi Universal Declaration of Human Rights bukan hanya pada tataran konsep "universalitasnya" yang sering dipertanyakan, tetapi lebih penting lagi adalah masalah aplikasi konsep yang harus melintas batas kultur dan masa. Ketika masyarakat global sekarang ini banyak ditandai dengan beragamnya konflik kepentingan, adalah sangat susah, untuk tidak mengatakan mustahil, deklarasi HAM bisa diterima oleh setiap negara dan diterapkan di setiap waktu dan tempat. ${ }^{25}$

25 H. Amir Mahmud, makalah Seminar Penegakkan Syariah Islam dan Refleksi HAM (Diskusi teori tentang Islam dan HAM, penyelenggara PUSHAM UII tanggal 13 Agustus 2008). 
Akan tetapi satu hal yang perlu di pahami di luar perdebatan tentang sulitnya deklarasi HAM diterima, bahwa adanya hubungan paralel antara ajaranajaran Islam dengan HAM yang dielaborasi sebagai suatu realita bahwa nilai-nilai universal tidak akan bertentangan dengan nilai-nilai universal lainnya. Ada titik temu (common values/kalimatun sawā) antara Syari'ah dengan konsep HAM dan konsep manusia apapun yang menyerukan kebajikan-kebajikan universal. Islam adalah agama rahmatal lil'ālamin (agama yang mengayomi seluruh alam). Abula'la Maududi dalam tulisannya Human Rights, the West and Islam menyebutkan bahwa:" when we speak of human rights in Islam we really mean that these rights have been granted by God; they have not been granted by any king or by any legislative assembly". ${ }^{26}$

Islam mengakui perbedaan sebagai kenyataan tak terbantahkan. Dengan pengakuan ini, Islam menghormati keragaman dan menganjurkan agar keragaman menjadi instrumen kerja sama di antara manusia, sehingga perbedaan adalah sunnatullah, karena dengannya manusia bisa saling melengkapi (give and take) antara satu dengan yang lain sesuai dengan prinsip-prinsip kedudukannya sebagai manusia. Sebagaimana dalam Al-Qur'an di Jelaskan Surah, 49: 11-13.

11. Hai orang-orang yang beriman, janganlah sekumpulan orang lakilaki merendahkan kumpulan yang lain, boleh jadi yang ditertawakan itu lebih baik dari mereka. dan jangan pula sekumpulan perempuan merendahkan kumpulan lainnya, boleh jadi yang direndahkan itu lebih baik. Dan janganlah suka mencela dirimu sendiri 27 dan jangan memanggil dengan gelaran yang mengandung ejekan. Seburuk-buruk panggilan adalah (panggilan) yang buruk sesudah iman $^{28}$ dan barangsiapa yang tidak bertobat, maka mereka itulah orang-orang yang zalim.

12. Hai orang-orang yang beriman, jauhilah kebanyakan purbasangka (kecurigaan), karena sebagian dari purba-sangka itu dosa. Dan

26 Tahir Mahmood (edited), Human Right in Islamic Law, (Genuine Publicatins Pvt. Ltd, New Delhi, 1993).

27 Jangan mencela dirimu sendiri maksudnya ialah mencela antara sesama mukmin karana orangorang mukmin seperti satu tubuh.

${ }^{28}$ Panggilan yang buruk ialah gelar yang tidak disukai oleh orang yang digelari, seperti panggilan kepada orang yang sudah beriman, dengan panggilan seperti: Hai fasik, Hai kafir dan sebagainya. 
janganlah mencari-cari keburukan orang dan janganlah menggunjingkan satu sama lain. Adakah seorang di antara kamu yang suka memakan daging saudaranya yang sudah mati? Maka tentulah kamu merasa jijik kepadanya, dan bertakwalah kepada Allah. Sesungguhnya Allah Maha Penerima Taubat lagi Maha Penyayang.

13. Hai manusia, Sesungguhnya kami menciptakan kamu dari seorang laki-laki dan seorang perempuan dan menjadikan kamu berbangsabangsa dan bersuku-suku supaya kamu saling kenal-mengenal. Sesungguhnya orang yang paling mulia diantara kamu disisi Allah ialah orang yang paling taqwa diantara kamu. Sesungguhnya Allah Maha mengetahui lagi Maha Mengenal.

\section{Penutup}

1. Dalam pluralisme dunia modern saat ini Pemahaman mendasar HAM merupakan elemen penting sebagai perekat bagi kehidupan masyarakat. Walaupun sangat sulit untuk memaksakan satu standar paradigma atau worldview tersebut.

2. Konsep HAM dalam Islam dibagi dua macam dilihat dari kategori huquuqul ibad. Pertama, HAM yang keberadaannya dapat diselenggarakan oleh suatu negara, yang di sebut sebagai hak-hak legal. Kedua, adalah HAM yang keberadaannya tidak secara langsung dapat dilaksanakan oleh suatu negara, yang dapat disebut sebagai hak-hak moral.

3. Bahwa Adanya hubungan paralel antara ajaran-ajaran Islam dengan HAM yang di elaborasi sebagai suatu realita bahwa nilai-nilai HAM tidak akan bertentangan dengan nilai-nilai universal lainnya. Ada titik temu (common values/kalimatun sawā) antara Syari'ah dengan konsep HAM dan konsep manusia yang menyerukan kebajikan-kebajikan menyeluruh. Islam agama rahmatal lil'âlamin (agama yang mengayomi seluruh alam), sehingga dengan pengakuan ini, Islam menghormati keragaman dan menganjurkan agar keragaman menjadi instrumen kerja sama di antara manusia, sehingga perbedaan adalah sunnatullah, karena dengannya manusia bisa saling 
melengkapi (take and give) antara satu dengan yang lain sesuai dengan prinsip-prinsip kedudukannya sebagai manusia.

\section{Daftar Pustaka}

A. Baderin, Mashood, 2003. International Human Rights And Islamic Law, London: Oxford University Press.

Brohi, A.K. in Altaf Gauhar, 1978, Islam and Human Rights, Islamic Council of Europe.

Arkoun, M., 2001. Islam Kontemporer menuju dialog antar agama di terjemahkan dari rethinking Islam Today, Yogyakarta: Pustaka Pelajar

Budiardjo, Miriam, 1999. Dasar-dasar Ilmu Politik. Jakarta: Penerbit PT. Gramedia Pustaka Utama.

Effendi, A. Masyur, 1980. tempat Hak-hak Asasi Manusia dalam Hukum Internasional/Nasional, Bandung : Penerbit Alumni.

El-Affendi Abdelwahab, 2001. Rethinking Islam And Modernity (Essays In Honour Of Fathi Osman, London: The Islamic Fondation In Association With The Maghrib Centre For Research.

J. Friedrich, Carl, 1969. The Philosophy of Law in Historical Perspektive, Chicago \& London: Chicago University.

Kung, Hans and Moltmann, Jiirgen, eds., 1990. The Ethics of World Religions and Human Rights Philadelphia. Concilium, New York, NY, USA.

Lurton, Douglas, 1942. Roosevelt's Foreign Policy, 1933 1941: Franklin D. Roosevelt's Unedited Speeches Toronto: Longmans, Green.

Lindholm Tore and Vogt Kari, 1993. Islamic Law Reform And Human Rights (Challenges and Rejoinders), Oslo: Nordic Human Rights Publications.

Litle David, Kesley John, dan A.Sachedina Abdulaziz, 1997. Kajian Lintas Kultural Islam-Barat Kebebasan Agama dan HAM, Yogyakarta : Pustaka Pelajar Offset.

Mahmood, Tahir (edited), 1993. Human Right in Islamic Law, New Delhi: Genuine Publicatins Pvt.Ltd .

Mayer Ann Elizabeth, 1991. Islam Tradition an Politics Human Rights, London: Westview Press, Pinter Publisher.

Mulia, Musdah, 2010. Islam dan Hak Asasi Manusia Konsep dan Implementasinya, Yogyakarta: Naufan Pustaka.

Mahmud, H. Amir, makalah Seminar Penegakkan Syariah Islam dan Refleksi HAM (Diskusi teori tentang Islam dan HAM, penyelenggara PUSHAM UII tanggal 13 Agustus 2008).

Osman Fathi, Islam And Human Right: The Challenge To Muslim And The Word, dalam Abdel Wahab Effendi,Rechthinking Islam and Mederenity.

W Nickel, 1971. James, ed., Basic Documents on Human Rights (Oxford: Clarendon Press), 93-105 